\title{
Bioethics applied health: internationalist perspective
}

\author{
Maria Lucia de Moura Costa \\ NursingFaculty. Master in Education, St. CamillusSchool of Nursing, Rio de Janeiro Brazil \\ Email address: \\ lucidalv@yahoo.com.br
}

\section{To cite this article:}

Maria Lucia de Moura Costa. Bioethics Applied Health: Internationalist Perspective. Science Journal of Public Health. Vol. 1, No. 3, 2013, pp. 147-155. doi: 10.11648/j.sjph.20130103.17

\begin{abstract}
This study was based on a discussion about the ethics and bioethics in Brazil and othercountries, where we chose a bibliography of the publications from national and international, publications.
\end{abstract}

Keywords: Health, World, Ethics, Bioética

\section{Introduction}

Reflections, ideas and essays that offer benefic patterns about what is fake or real, based on current moral standards, are becoming part of the formation of health professionals, such as biologists, nurses, lawyers, economists, engineers, journalists, among others.

So one can notice that, besides the formation for the exercise of a profession, there is the need to recognize and critically examine with competence and responsability the ethical conflicts and their possible consequences, while making decisions concearning human lives. In this perspective, the study had as an objective to analize the internacional cooperation between continents, principally in the Bioethics area, and wich are the contribuitions, challenges and possibilities in the brazilian politics.

Examining contemporary bioethics and reflecting about ethical questions that rise constantly, we can explain Bioethics as the science of life. Descartes (2006), brought the need of moral standards and the main ideals of human behavior"

"To examine life, it is necessary, once, to doubt the most as possible about everything".

It is known that bioethics propositions are necessarily limited, due to the actual social situation,wich brings a break between rationality and morality. The main reason for this intelectual break comes from the fact that we notice a rising anemia on the public debate about nature and morality's function, only moral justifications, that don't lead to a unifying God, genesis of what is right and worng, of good and evil. (Engelhardt 1996, p.14)

\section{Theoretical Background}

It is known that in bioethics there are some introductory questions that become important for one to get along with this science. What is it? How to proceed? Are Bioethics science or a treatise inside science itself? Or is it just a discussion field for several specific subjetcs? A well-known author says "Ethics are one of those things that everyone knows, but that are hard to explain when asked". (Valls, 1994, p.5).

Some recent studies made the effort of retrieve the historical genesis of the term bioethics, and also the intention of those who used it to express a collection of challenges that rise for humanity. The term was first used in the seventies, by Van Rensselaer Potter, doctor in biochemistry, researcher and oncologist from Wisconsin University, in the U.S.A. (Anjos, 2001, p.17, 18).

Along with a number of authors and scholars, there is no perception about the precise difference between ethics (from the greekéthos, way of being) and morality (from latinmores, costumes). This is why, based only in the semanthicalressemblance between the terms, one is treated as the perfect synonym of the other. In the practics of health professionals, guided by a professional ethics code, the confusion occurs between the real meaning of ethics and deontology (from the greekdeón, duty). (Soares e Piñeiro, 2002 p.21).

\subsection{Bioethical Relation and Human Rights}

Seen through this opticas, Professor Van Rensselaer Potter released a mental representation between the sciences of live and the study of the living creatures, contributing to the progression of the bioethics concept 
together with biomedicine's improvements. One contention about ethics in the medic-pacient relation became present in the recognition of moral standards and values where we can quote the Nuremberg delcaration, that searchs to promote life in the free acting course, as the discussion of ethical problems began to rise in all areas of medicine, awakening the reflection about the human being's dignity, since principal actors is this revolution, said that knowing medicine separate form bioethics is not possible.

After this understanding, it becomes necessary to approach the correlation between the causal link, bioethics and human rights, because they work together in defense and respect of life, in other words, to perpetuate life. About the countries that in majority reflect and respect the ethics of life, based on the triad (ethics, bioethics and human rights), with relevant focus and possible of proving the scientificity of the genesis of the word when using the terms stem cell, abortion, cloning, euthanasia, hunger, violence, at last, the agression towards human beings.

According to Aragão, (2000),

"The rights about human nature, universally recognized by individuals and humanity, in general, may survive their realizations".

Moraes (2002) stands for a more constitucional perspective, choosing the expression:

"Fundamental human rights are considered as a set of institutionalized rights and warantees of the human being that have as main purpose the respect for dignity, by the protection against the will of State power and the estabilishment of minimal life and human personality development conditions".

We can assert, according to some authors, that "All scientific advance that is made by stomping on human dignity brings with itself a negative charge and must be reconsidered" (Pessini and Barchifontaine, 1996, p.26).

Just after this exposition, the obligations toward living creatures, not olny human beings, are a knowledge based upon moral standards, including intuition, racionality, objectivity and subjectivity, the tangible and imaginary, so guiding to experience values and reflections, since one cannot apprize someone else, even because changing behavior is very difficult with races, beliefs, cultures and different values.

To continue, men need to be seen as a transdimensional being, with northing principles, with opositions and complementarity, as one part of us stands in the physical plan and the other, in the spiritual plan.

Seen by another side, historians rarely have the oportunity to register the birth of a discipline, specially if it rises without an important scientific discovery. In Latin America, it was incorporated in an hesitant way. In Argentina, Colombia and Brazil, however, bioethics came with success and acceptance.

In this sense, bioethics in Brazil has a bit more then 15 years in academic and institutional activities, being considered young and late, worried about reflecting, comprehending and solving ancient and new challenges brought by technologic science in the world of human health and biomedical research. In matter of fact, since de decade of 1990, bioethics began to be discussed in Brazil with a bigger emphasis, from three important and fundamental phenomenons: the foundation od the Brazilian Society of Bioethics (SBB), in 1995; the release of the Bioethical Revue by the Federal Medicine Counsel, in 1993; and the elaboration of the Resolution 196/96, in wich Dr. William SaadHossne is considered the intelectual father and founder of the SBB.

In this context it was created the NacionalComission of Ethic in Research (CONEP), a commission of the Nacional Council of Health (CNS), which established the rules to ethic research in human beings in 1996. There are 600 committes related to the subject, probably created between 1996 and 2011. These committees count with over ten thousand collaborators, spread all over the country. (Brasil, 2006).

Besides, it's independent of corporative and institucional influence. One of its features it's the composition multi and transdisciplinary, counting with the participation of all brazilian states. (Pessini and Barchifontaine, 2007 p.99, 100).

In this sense we must understand that a critical reading is proposed, and a tribute to all those who iniciated the bioethical reflexion in Latin America. Argentina open the way, and the first program ibero-american of bioethics was on Institute of Medical Humanities, created by Dr. José Alberto Mainetti, in 1972. (Mainetti and Marta, 2007, p.36, 37).

With that, the fast progress of technology, ally to scientificity, formulates questions, embarrassing situations and even ethical challenges. The areas with most progress, and that at the same time created encompassing and extense ethical questions, keeping the connection with the area of performance of Bioethics, went to health areas, environment and the life of the human being as a whole. It is known that day after day, society finds itself facing embarrassing situations that only can be added or separated within the dualistic perception multi and interdisciplinary, evaluating its effects on the present and future life.

Proceeding, Uruguai, maybe, was the first country to legislate on the possibility of euthanasia being performed in the world. On 1. August 1934, when the current Uruguayan Penal Code entered into force, it was characterized the "compassionate homicide", on article 37 of chapter III, that addresses the question of the causes of impunity. Dr. Jiménez de Asúa was an important spanish lawyer in the field of Criminal Law, in the beginning of the 20th century. It was political, mason, eugenicist and defended the right to euthanasia, characterizing it as "compassionate homicide".

Shortly after this exposure, in June 1925, Dr. Jimenez has lectured in Montevideo / Uruguay, on the subject of the right to die.These lectures were published by the University of the Republic, and quickly sold out. The impact of these conferences was so huge, that his doctrine was the basis for the establishment of "Homicide Pious", incorporated into 
the Uruguayan Penal Code, 1934, Act 9414, to June 29, 1934. (SMU, 1995, p.1, 2)

Continuing, in Chile there was only one example of successful institutionalization, since, initially, philosophers have not shown interest in medical and biological issues. Only in 1983 was created at the University of Chile one Interdisciplinary Center for Bioethics and developed the first manuals for Bioethics. (Kottow, 2007 p.151, 152).

Viewed from another aspect, Paraguay development of bioethics began in the late 1980s, growing slightly slower than in the other countries of South America, and gained strenght with the formation in the hospitals of bioethics committees, study groups, annual courses and the recognition in 2004 of a National Commission for the development of bioethics.

Complementing the first civilian institution was the Pro Bioethics, a non-profit organization created in June 1995. It was conceived as a permanent institution of study, analysis and training to cooperate in the process of regulating the behavior of health workers, other professionals and the general population committed to respect for life and the right to health protection, integrity, autonomy and dignity of the human person, the preservation of ecosystems. (Ascurra, 2007, p.237).

In Bolivia, the records of bioethical activities date back to 1991 until between late October and early November 2001. The Impeller Ethics and Bioethics Committee (CIEB) organized the course "Ethics in Research" and good clinical practices in collaboration with the Medical College Department of La Paz and counting as visiting professors and doctors Jaime Soto and Julia Toledo, from Colombia. (Eduardo, 2007, p 123-127).

Note that there are three main documents of an international character which stipulate standards and ethical guidelines for research with human beings. The Nuremberg Code in 1947, which was prepared by the U.S. military to serve as a subsidy to the judges of the Nuremberg Tribunal, which prevailed crimes against humanity.

The Declaration of Helsinki developed by the World Medical Association in Finland in June 1964 called for ethical principles to provide guidance to doctors and other health professionals participating in the clinical research involving human subjects, which is meant to work on identifiable human material or identifiable data by the 18th World Medical Assembly, and was amended at the 29th World Medical Assembly in Tokyo, Japan in October 1975.

Just after, came the 35th World Medical Assembly in Italy in 1983, the 41st World Medical Assembly in Hong Kong in September 1989, the 48th General Assembly in South Africa in October 1993 and the penultimate General Assembly in Scotland in 2000. Continuing, the third document, which are proposed international guidelines for biomedical research on human subjects in 1982, from the Council for International Organizations of Medical Sciences (CIOMS) and the World Health Organization (WHO).

The three documents were prepared or by doctors, or corporations with strong medical features, and essentially concerned doctors and medical research. One can not fail to recognize, therefore, strong medical bias both in genesis and content of the documents. (WHO, 2002, p. 7,8,9, and 131).

With this reasoning, it was no surprise that the Bioethics have reached amazing dimensions, because it is widely publicized on TV, internet, magazines, journals, studies and news on some fact that might have shocked society, as well as there are several actions and projects just as educational organizations that foster and promote national and worldwide congresses about Bioethics.

Just after this exposure, remember that in Peru bioethics has not yet acquired its own identity. The bioethics goes beyond the ethical issues of medical practice. You must create bioethics committees governing medical actions related to organ transplants, a fact that shows recognition of Peru in relation to the recognition of this discipline.

In fact, the bioethics movement in Peru began in 1988 when the directors of the School of Medicine of the period began to convene twenty doctors with vocation in ethics, bioethics and deontology to participate in roundtables. In March 1993 happen the first preparatory meeting of the Peruvian Association of Bioethics, having invited 70 professionals, of which 35 were present. Finally on May 2, 1993, founded the Peruvian Association of Bioethics.(Zuloaga, 2007 p. 257, 260, 262).

It is important to remember that the Constitution of the Republic of Ecuador refers explicitly to human rights related to the life, health, security groups, social vulnerability, culture, education, science, technology and the environment, establishing the cosmic balance that unites people, their cultures, their history, their habitat and survival, with guidance universalist ethics that combines moral values and science and technology. The National Health Policy is based on his philosophy and humanity in the "principles of universality, equity, solidarity, quality, diversity, efficiency, ethics and integrity." (Acosta et al, 2009 , p.243 to 245 ).

Remember that, in Colombia, bioethics began in 1976. Dr. Jaime Escobar Triana, as director of the Intensive Care Unit of the Hospital San Juan de Dios, University Center, Faculty of Medicine, National University, concerned with patients' rights and the right to die with dignity, held a series of seminars at the College of Surgeons of Colombia and the Faculty of Medicine at the University of Rosario.

With this understanding, the history of bioethics in Colombia was classified into three periods: the pre-history of bioethics from 1975 to 1992 , characterized by the introduction to the topic and socialization; the second, with the normalization of bioethics, until 1997; the third period from 1997 to 2002, called amplitude or bioethical relationships, and currently the fourth period is characterized by investigation programs. In 2001, was consolidated the first master degree in bioethics at Colombia, in Forest University. (Gutierrez and Victor, 2006, p. 12). 
Seen from another perspective as in other latitudes, bioethics has its origin in Venezuela linked to academic circles, units of social welfare and research. The first committees were implemented in 1995, and at the beginning of the century, the first national congress of bioethics was performed.

With regard to 2001, the Bioethics Committee is regulated by the Law on Science Technology and Innovation (LOCTI). Today, in major cities, public hospitals and private clinics, universities and research centers have trained people in question. (Ludwig, 2007 p.1).

Importantly, Cuba is a country that for decades was a sui generis case in the context of Latin America, because despite the vicissitudes of regional policy remained focused on building a social project, with guidance ofMartí and Marxist. The advent of revolutionary power in 1959 completely reversed the national scene by advocating the Marxist principle of equal access to health care as a human right and responsibility of the state organization of the National Health System

Thus, the normative ethics in health care became a responsibility of the Ministry of Public Health, until, in the mid-1980s, were promulgated the principles of medical ethics, and occurred the process of constitution of the Committees of Medical Ethics at all units and levels of organization of the National Health System (Sariego, 2007, p. 161-163).

The National Bioethics Committee of Mexico has gained more importance and status over time. It was the first settlement in 1992 to discuss issues related to bioethics, and in 2000, a presidential agreement declared it as a permanent body. Since 2005 , has been recognized by a presidential decree, as more independent body.

It is the official responsible for the definition of national policies, and finally, it is interesting to note that the Commission has been part of the Intergovernmental Bioethics Committee of UNESCO and participated in the discussions and final drafting of the Universal Declaration on Bioethics and Human Rights. Currently, also participates in meetings of the CDBI, in the Council of Europe, since Mexico has been accepted as a observer state. (Karasik, 2010, p.2).

Another significant highlight is the United Nations Development Programme, when using the term "South" referring to developing countries, and has been used as part of the abbreviation of international relations since the 1970s. The contribution of bioethics to the formulation, implementation and evaluation of South-South cooperation as a realization of the ideals of international relations authoritative solidarity, consensus and equity, represent a challenge against the health situation and trends in the land.

Therefore, international cooperation began to promote the interests of all people, being seen as the most important subject of all countries.Social development and human resources now also cover issues such as health, morbidity, safety, social, human rights and equity of a company.

We realize, as we move into the 21 st century, a new paradigm of development cooperation has emerged as a central element. It is based on a new sense of the dynamics of how knowledge is generated, how human resources are used, and an acknowledgment of the reservoir rich in knowledge that exists in developing countries.

Just after such exposure, we find new information and technologicalcommunications allowing this knowledge to be shared with a minimal cost. The purpose of technical cooperation among developing countries (TCDC) in the coming years will be to ensure that the South will rise on its own rich heritage in a world of equals. (Brow, Zhou, Annan, 2004, p.18, 23).

Promoting ethics is "sine qua non" for any area, be it health, education or environment. As a consequence, the expression of contemporary shows as well as an efficient administration, a deep adherence to standards of conduct and that also is not subject to individual determination, but that is the option of people who are part of any organization.

\subsection{European Comunnity}

The European scientific community is divided, as some countries agree with the technological possibility of therapeutic cloning, believing it to be a hope for the future medicine. Others disagree. In other countries, research on stem cells is controlled by the ethics committee of the hospital while in others both therapeutic cloning as a reproductive, there is no regulation.

In 1999, the World Medical Association (WMA) adopted a resolution recommending that all medical schools have a duty to include the teaching of medical ethics and human rights as a required course in their curricula. Until now, we have the knowledge that there is still no detailed study regarding the implementation of the new curriculum in medical schools of the European Union since its expansion in 2004. (Claudot et al, 2007 p.4).

The march of science, inseparable from economic development, seems to obey an autonomous logic, which would be questionable whether the guarantees were not put to ensure control of technological risks and safeguard the fundamental rights of man. "There is a chance that ethical values are expanded, both in matters of biomedicine, as in all others, in a world where concern for human goals in general seems to be down." (Lenoir, 2009, p. 2.5).

\subsection{Bioethics in the United States}

The bioethics movement started in the United States in the early 1970s, completed 41 years of existence. In the origins of the neologism "bioethics", we have the pioneerism of the biochemist Potter, and the Institute Kennedy of Bioethics (Washington, DC). At the time of its emergence Bioethics was not a body of doctrine.

And to enrich the environment of Bioethics, was discovered recently that the first person to coin the neologism Bioethics was FritzJahar, a German Lutheran theologian and educator, in 1927, staying hidden in the dust of time due to the facts of nationalism and Nazi World War 
II. (Morais, 2011, p. 11).

In 1971, Georgetown University formalizes and institutionalizes bioethics with academic support prevailing until the following decades.

It seems that bioethics must refer to principles because, well, it immediately clarifies the path taken in relation to the choices that the major historical transformations of contemporary medicine pose to humanity (Alfonso, 2007, p.64).

It is noteworthy that one of the greatest scholars in intercultural issue is Geert Hofstede, since in his studies, he was able to characterize five basic points that differentiate or equate national cultures: the relationship with authority, the relation of the individual to society, the individual concept of masculinity and femininity, the ways of dealing with conflict and uncertainty and long-term perspective. (Hofstede, 1997, p.34.)

\section{African Continent}

The "Program Eager - Africa" is designed to promote ethical conduct for Genomic Research in Africa, and is generously funded by a grant from the United States' National Institutes of Health, in 2011. The work is done by developing a roadmap for research and practice ethics of genomic research in Africa, as the continent is on the threshold of emerging genomic revolution with plans to increase training and research capacity in African genomics.

Therefore, it is necessary to urgently develop a proposed ethical formation in the study of the genetics research in Africa. The Human Heredity and Health in Africa (H3Africa) aim to facilitate a contemporary research approach for the study of genomic and environmental determinants of common diseases with the goal of improving the health of African populations.

To accomplish this, the H3Africa Initiative aims to create and support the development of the necessary expertise among African scientists, and to establish networks of African investigators. To achieve this, H3Africa Initiative aims to create and support the development of skills among African scientists, and establish networks of African researchers. It is anticipated that studies conducted under the initiative H3Africa inform subsequent strategies to address more broadly inequalities in health and noncommunicable diseases.

This argument makes it clear that we must evaluate the ethical aspects of genomics research in the continent, understanding also the ethical aspects of genomics research from an African perspective since it is an emerging field of bioethics, in order to strengthen collaborations and promote a deepening and high quality research. (Ademola et al., 2011).

\subsection{Asian Countries}

Correspondence to: Dr F ClaudotWithin a Program in Human Research Protection (HRPP), the responsibilities should be delegated to provide ethical review and oversight of research. These responsibilities are assigned in different ways in different organizations,most to the Ethics Committee (EC), that along with systems and support staff, provide these functions.

A CE is usually a body established under laws, regulations, codes and guidelines to protect the rights and welfare of human participants. The structure, composition, operations and review standards of CE are defined by laws, regulations, codes and guides. The purpose of this manual is an initiative of Pfizer U.S., which provided the Clinical Research Center at the University of Hong Kong Administrative Region (ERA) and the People's Republic of China (PR) a grant for its development.

The layout protocol was generally accepted by Pfizer in July 2009. The subsidy was not binding, that is, Pfizer did not interfere in any way in the project, except for non required comments about the final product. (Karlber and Marjorie, 2011 p.100).

In this context this role is well established in several international ethical guidelines (Declaration of Helsinki, International Guidelines for Biomedical Research involving Human Beings - CIOMS and Handbook for Good Clinical Practice - Version Harmonized Tripartite USA, Europe and Japan - ICH) and National (Resolution CNS 196/96 and complementary), these guidelines that emphasize the need for ethical and scientific review of research involving human subjects in order to safeguard the dignity, rights, safety and welfare of the research subject.

Actually the Manual above aims to provide a unified standard for the European Union, Japan and the United States. In preparing the text, were taken into consideration the standards of Australia, Canada, the Nordic Countries and the World Health Organization (Brazil, 2007).

\section{Methodology}

With the purpose of defining the object of study and field research to the reality that it was intended to apprehend, was selected productions in the form of articles published in national and international journals, lifting items over the internet, books and magazines, considering a limit time where the author has chosen to cover the years 1995 to 2011.

The instrument contemplated the data: Article or matter, the author (s), year of publication, in the case of a quantitative descriptive study.

In this situation, Mimayo, (1993), p.23, classifies the research as:

"Basic activity of the sciences in their inquiry and discovery of reality. It is an attitude and a constant pursuit of theoretical practice that defines a process inherently unfinished and permanent. It is an activity of successive approximation of reality that never runs out, making a particular combination of theory and data.".

The selection was based on the similarity of the goals of this study subjects, excluding those who, although they reveal themselves in a search result, did not address the 
issue from the point of view of universal bioethics.

Demo (1996) already reflects the research as:

"A systematic critical and creative questioning, plus competent intervention in reality or critical dialogue with the permanent reality in theoretical and practical sense."

The analysis of data extracted from the articles were descriptive, enabling to observe, count, describe and classify the data in order to gather the knowledge produced on the theme explored in the review.

Thus, describing, counting, and sorting is a prerequisite for a good observer, according to Gil, (1999) which states:

"The survey is a formal and systematic development of the scientific method. The fundamental objective of the research is to discover answers to problems by employing scientific procedures."

\section{Results and Discussion of Studies}

We identified a total of 33 studies, including books, electronic magazines and printed, of which twenty-four studies in Portuguese available online in its entirety, with the majority of the authors belonging to field of health, but also finding directors of institutions, managers, teachers, philosophers who contributed providing studies and research on the internet. In 2007, there were more publications relying on the internet articles, books, magazines, totaling 12 studies. In the years 1997, 2002, 2006 and 2009, only two studies were found. Already in 1996 and 2011, three studies were found. In 1994, 1995, 2000, 2001, 2004 and 2010, only one study was found on the subject at hand.

Some studies relate bioethics human rights, others perceive that acceptance of bioethics took longer. For others, adherence was immediate. It was also noticed that some research advocate euthanasia, classifying it as "compassionate homicide". Others showed no interest in the subject. Some countries still resist, forming councils and meetings to decide, as described in the tables below. In fact, the vast majority of developing countries, and others recognized as being developed, has similar characteristics in their commissions of Ethics and Bioethics. Here are the pictures with the studies found.

Chart 1. Articles collected over the internet

\begin{tabular}{|c|c|c|}
\hline Nome do Artigo & Autor (es) & Ano de publicação \\
\hline \multicolumn{3}{|l|}{ The Foundations of Bioethics } \\
\hline New York, & Engelhardt Hugo Tristam Jr.. & 1996 \\
\hline Sindicato Médico Del Uruguai & Sindicato de Montevidéu & \\
\hline \multicolumn{3}{|l|}{ Seminário de Bioética y Legislacion } \\
\hline Montevidéu & & 1995 \\
\hline La Bioética em La Formacion Recursos & Acosta Cárdenas Suzana;Torres Carlos & \\
\hline Humanos de La Saúde. Situacionactual & Bandeiras Garcia Agustín; Edmundo Esteves M & \\
\hline \multirow[t]{2}{*}{ y desafios em El Ecuador - Quito } & $\begin{array}{l}\text { Padron Miranda Elena M yriam; Marco R. } \\
\text { Garcia C }\end{array}$ & \\
\hline & Luiz Cantos Martha; SarrazinDavila & 2009 \\
\hline Bioética in Colômbia & Gutierrez Mendez Victor Manuel & \\
\hline Colômbia, Bogotá. & & 2006 \\
\hline La Bioética em Venezuela, & Ludwig Schmidt H. & \\
\hline primeirashuellas. & & 2007 \\
\hline Salud. The National Commission & KarasikKawa Simon & \\
\hline \multicolumn{3}{|l|}{ OfBioethics. Gobierno Federal. } \\
\hline Estados Unidos Mexicanos & & 2010 \\
\hline Forging a Global South United Nations & Brow Malloch; Zhou Yiping; & \\
\hline Day for South-South Cooperation, & Annan Kofi. & \\
\hline New York & & 2004 \\
\hline Ensino de Ética na Europa & ClaudotFrederic; François Alla Ducrocq & \\
\hline França. & Henry Coudane & 2007 \\
\hline Cultures and Organizations & HofstedeGerte & \\
\hline New York & & 1997 \\
\hline Promoting ethical Conduct ofAdemola J. & Ajuwon; Clemente A Adebamowo; & \\
\hline Genomics Research in Africa & Temidayo O Ogundiram; OlaitanSouannwo; & \\
\hline \multirow[t]{2}{*}{ Nigéria } & Adefolarin O Malomo; Olayemi O Omotade; & \\
\hline & Emmanuel B. Omobowale; Simisola O Akintola & \\
\hline AdebayoAdejumo. & & 2011 \\
\hline \multicolumn{3}{|l|}{ Revisão de Estudos Clínicos;Kaarlber Johan } \\
\hline \multicolumn{3}{|l|}{ PE ; Marjorie A Speers. } \\
\hline \multicolumn{3}{|l|}{ Um guia para o comitê de ética. $\mathrm{Re}$} \\
\hline \multicolumn{3}{|l|}{ Publica Popular da China (RP) e Região } \\
\hline \multicolumn{3}{|l|}{ Administrativa de Hong Kong (RAE) } \\
\hline \multicolumn{3}{|l|}{ Estados Unidos - Washington } \\
\hline \multirow{4}{*}{$\begin{array}{l}\text { Promover o Ensino de Bioética no Mundo } \\
\text { Comitê Internacional de Bioéthique. } \\
\text { UNESCO. França. }\end{array}$} & & 2009 \\
\hline & Lenoir N & \\
\hline & & \\
\hline & & 2000 \\
\hline Capacitação para Comitês de Ética & Ministério da Saúde & \\
\hline e Pesquisa. Brasília & & 2006 \\
\hline
\end{tabular}




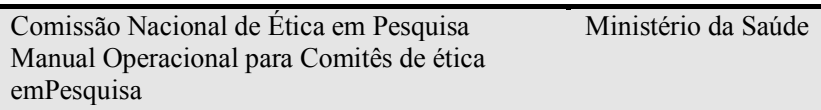

In this context, here is the table containing the studies that have been raised through books and magazines.

Chart 2. Studies raised through books and magazines

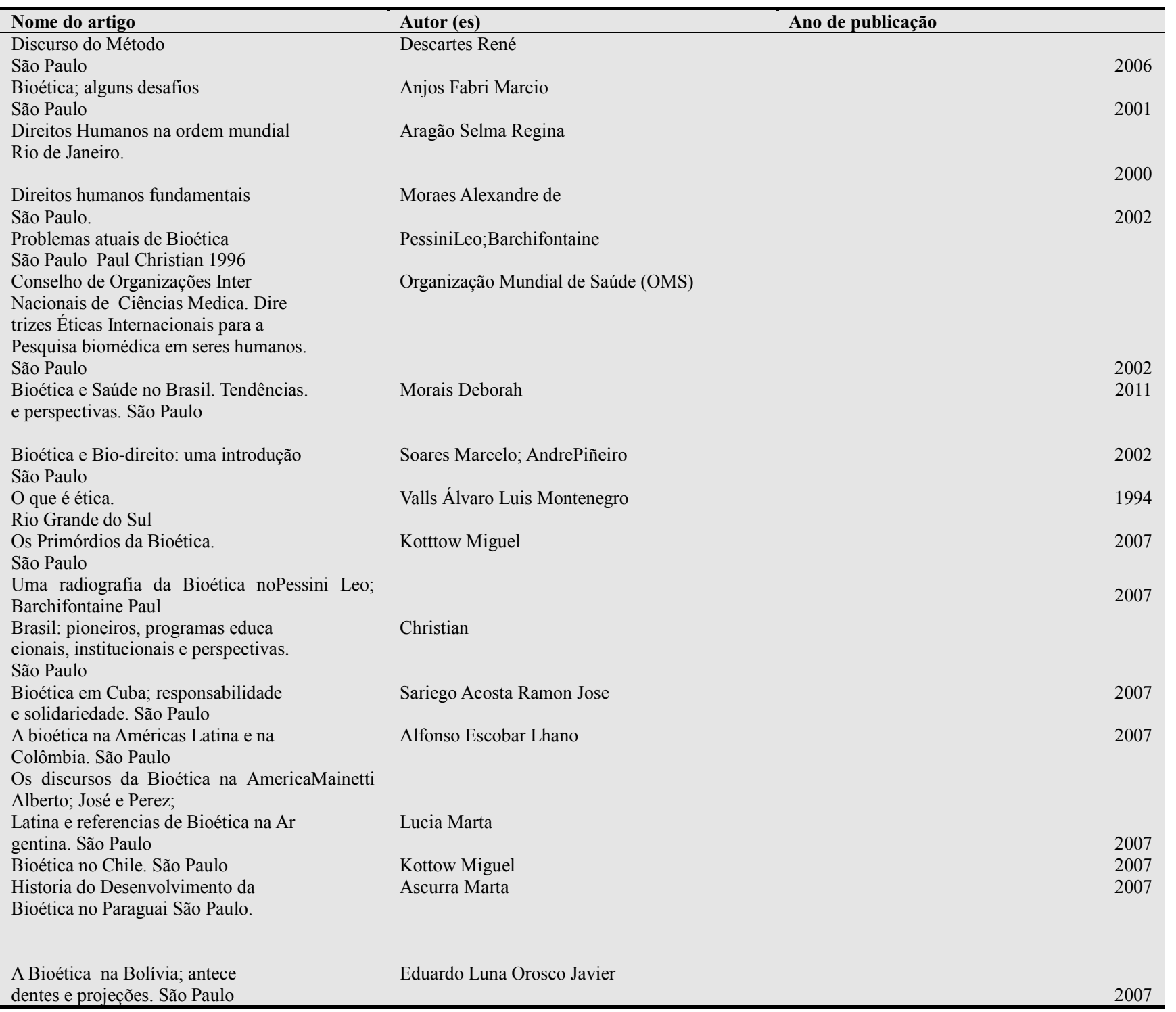

Anyway, discussions on accession to the discipline of ethics in universities and bioethics committees in health institutions, still walk at a slow pace. As stated Alfonso, in 2007, it seems that bioethics must refer to principles because, thus, it immediately clarifies the path taken toward choices that major historical transformations of contemporary medicine impose on humanity.

\section{Conclusion}

There was intention in this study to exhaust the subject, but highlight the issue of research with living beings, with an explanation of the debates and controversies surrounding the coming discussions about ethical discipline in the curriculum of universities and institutions in the area of Health, permeating the area of law, as has been the scope of reflective questions in the area of Health Sciences and Biological Sciences. As a result of the speed with which the technical / scientific presents itself, it seems that the very nobility of the human being was curtailed, being relegated to the background. And some authors have commented in this regard stating that "every scientific advance that is made trampling human dignity, carries a negative charge and should be rethought" (Pessini and Barchifontaine, 1996, p.26).

The health and life of humans, are invaluable assets. A 
distinct society can not determine the gradual transition from one stage, judged inferior to a more developed stage just to prove the technological capacity internal. We can not forget the growth and scientific discoveries through the Brazilian technology, with the Oswaldo Cruz Foundation, an institution known and respected throughout the world, since Brazil has been working in partnership with other countries in participating and collaborating with investments to minimize diseases and improve quality of life. Nothing more natural in this context that the creation of a Center for the Study of Bioethics for the countries of South America and the world, because health is a right and duty of the State.

\section{References}

[1] Acosta Cardenas S. etal.La Bioética em La Formacion Recursos Humanos de La Saúde. Situaciónactual y desafíosenelEcuador.OrganizacionPanamericana de LaSalud. Quito, 2009.

[2] AdemolaAjuwon et al. Promoting ethical Conduct of Genomics Research in Africa. 1. Review current knowledge of genomics research, its contribution to understanding gene-environment-disease association, population history and pharmacogenomics, and the interaction between these and bioethics.Eager África. Nigéria, 2011. Available in: http://h3africa.org/funding.cfm

[3] Alfonso Escobar Lhano. A bioética na America Latina e na Colômbia. Bioética na Ibero America. Historias e Perspectivas. Loyola, São Paulo, 2007.

[4] Anjos Fabri Marcio Bioética: alguns desafios. Coleção Bioética em perspectiva. Loyola, São Paulo, 2001.

[5] Aragão Selma Regina. Direitos Humanos na ordem mundial. Forense: Rio de Janeiro, 2000.

[6] Ascurra Marta. Historia do Desenvolvimento da Bioética no Paraguai. Bioética na ÍberoAmerica. Historias e perspectivas. Loyola, São Paulo, 2007.

[7] Brasil. Ministério da Saúde Secretaria de Ciência, Tecnologia e Insumos Estratégicos Departamento de Ciência e Tecnologia. Capacitação para Comitês de Ética e pesquisa. Brasília: Ministério da Saúde 2006.

[8] Brasil. Ministério da Saúde Centro de Referência e Treinamento DST/AIDS-SP. Normas e Manuais Técnicos. Cadernos Técnicos Brasília: Ministério da Saúde. 2007.

[9] Brown Malloch Mark; Zhou Yiping; Annan Kofi.Forging a Global South United. Nations Day for South-South Cooperation.- United Nations Development Programme. One United Nations Plaza. New York, 2004.

[10] Claudot Frederic et al; Ensino de Éticana Europa.JMed. Ethics 33.doi:10.1136 - França, 2007.

[11] Demo, Pedro. Pesquisa e construção de conhecimento. Rio deJaneiro: Tempo Brasileiro. 1996.

[12] Descartes, René. Discurso do método: São Paulo: Ícone. 2006.
[13] Eduardo Luna Orosco Javier. A Bioética na Bolívia. Antecedentes e Projeções. Bioética no Ibero America. Historias e perspectivas. São Paulo: Loyola, 2007.

[14] Engelhardt Hugo Tristam Jr..The Foundations of Bioethics, Oxford University Press, New York, 1996.

[15] Gil, Antonio. C. Métodos e técnicas de pesquisa social. São Paulo: Atlas. 1999.

[16] GutierrezMendez Victor Manuel.Bioética inColômbia. Precop. SCP. Modulo 4 ano 5. Colômbia, 2006.

[17] HofstedeGerte. Cultures and organizations. New York: McGraw-Hill; 1997.

[18] Kaarlber Johan PE e Marjorie A Speers.Revisão de Estudos Clínicos: Um Guia para o Comitê de Ética. Hong Kong. (RAE) e Republica Popular da China (RP). Associação para a Certificação de Programas de Proteção em Pesquisas em Humanos, Inc. Washington, DC, EUA, 2011.

[19] KarasikKawa Simon. Salud. TheNational Commission of Bioethics.Gobierno Federal. Estados Unidos Mexicanos, 2010. http://cnb-mexico.salud.gov.mx/index.html

[20] Kottow Miguel. Bioética no Chile. Bioética no Ibero America. Historias e Perspectivas. São Paulo: Loyola. 2007.

[21] Kottow Miguel. OsPrimórdios da Bioética. Bioética na Ibero - America Histórica e Perspectivas. São Paulo: Loyola. 2007

[22] Lenoir N. Promover o Ensino de Bioética no Mundo. Comitê Internacional de Bioéthique United NationsEducationalScientificand Cultural Organizations (UNESCO) França: 2009.

[23] Ludwig Schmidt H. La Bioética en Venezuela, primerashuellas. - Centro Universitário São Camilo. 1(2): 24-38. Doctorado de Ingeniería Biomédica y Hospitalaria São Paulo: Bioethikos. 2007.

[24] Mainetti Alberto José; Perez Lucia Marta. Os Discursos da Bioética na America Latina e referencias de Bioética na Argentina. Bioética na Ibero America. Historias e perspectivas. Loyola. São Paulo, 2007.

[25] Minayo, Maria Cecília de Souza. O desafio do conhecimento. São Paulo: Hucitec 1993

[26] Moraes Alexandre de. Direitos Humanos Fundamentais: teoria geral. $4^{\mathrm{a}}$ ed. Atlas: São Paulo: 2002.

[27] Morais Deborah. Bioética e saúde no Brasil. Tendências e perspectivas. Revista São Camilo. Educação, Saúde e Assistência Social. São Paulo: Bimestral $\mathrm{n}^{\circ} 7$ setembro/outubro. São Paulo: 2011.

[28] Organização Mundial de Saúde (OMS); Conselho de Organizações Internacionais de Ciências Medica. Diretrizes Éticas Internacionais para a pesquisa biomédica em seres humanos. São Paulo: Loyola. 2002.

[29] Pessini Leo, Barchifontaine Paul Christian. Problemas atuais de Bioética. $3^{\text {a }}$ ed. São Paulo: Loyola. 1996.

[30] Pessini Leo, Barchifontaine Paul Christian. Uma Radiografia da bioética no Brasil: pioneiros, programas educacionais e institucionais e perspectivas. São Paulo: Loyola. 2007. 
[31] Sariego Acosta Ramon Jose. Bioética em Cuba: responsabilidades e solidariedade. Bioética na Ibero America. Historias e Perspectivas. São Paulo: Loyola. 2007.

[32] Sindicato Médico del Uruguai. Seminário de Bioética y Legislación. Montevidéu Nordancomunidad, 1995. v1. 228 p. Fac.Ciências de laComunicación: 614.017 Montevidéu, 1993.
[33] Soares Marcelo Andre; Piñeiro Esteves Walter. Bioética e Biodireito; uma introdução. São Paulo: Loyola. 2002.

[34] Valls, AlvaroLuis Montenegro. O que é ética. 7a edição Ed.Brasiliense, Rio Grande do Sul, 1994 .Zuloaga Roberto Lhanos. Bioética no Peru. Bioética na Ibero America. Historias e Perspectivas. São Paulo: Loyola 2007. 